\title{
Perceived Financial Viability of Employees Training \& Development, Advertisement and Research \& Development for a Firm
}

\author{
Faid Gul ${ }^{1}$ \\ Rabia Umar ${ }^{2}$
}

\begin{abstract}
The main purpose of the current study is to examine the impact of three business processes expenditures i.e. research \& development $(R \& D)$, advertising and training \& development $(T \& D)$ on firm's perceived financial performance in developing country like Pakistan. Majority of the previous researches in this area have been done in developed countries so there is a need to conduct such a study in a developing country like Pakistan. The current study tries to make an in-depth investigation into the impact of $R \& D$, advertisement and $T \& D$ on perceived financial performance of a firm. The sample consists of 200 respondents from two industries of manufacturing sector i.e. pharmaceutical and cement industry. The study results are based on primary data which is been collected through the questionnaire. The study has made use of different statistical tools in order to substantiate the hypotheses been derived and these tools include descriptive statistics, correlation and regression analysis. Results indicate that $32 \%$ of variance in a firm's financial performance is due to the three independent variables. The study is beneficial to top management to increase their investments in these functional competencies to raise their performance as some of the firms in developing countries have the perception that amount invested in these areas are the expense so this study is helpful to change this perception.
\end{abstract}

Keywords: $R \& D, T \& D$, advertisement, firm performance, manufacturing sector

\section{INTRODUCTION}

Why do some companies outperform others? Why do some companies get success while others fail? Is there any impact of functional competencies of firm on their success or failure? What role does the $R \& D, T \& D$ and advertising processes play in the success or failure of a company? These issues and queries are explored in the current study. Porter (2008) concluded that companies that achieved international leadership made strategies by taking into consideration their distinctive competencies. Some of these competencies, according to $\mathrm{Li}$ (2000), are new product development, adopting and using latest technologies, use of effective training programs, using total quality management practices, and maintaining effective and long lasting relationship with suppliers. Thus R\&D, employees T\&D and strong marketing are some of the major business processes which can help in improving the performance of a company which ultimately can improve the industrial sector of any economy. Those industries that enjoy success and competitive edge over others are the ones that are good in strategies planning and implementation. Strategic planning is one of the core areas which can help the company to gain competitive edge and to outperform over others. Three of the main core strategic areas that help any company to outperform over others include the area of R\&D, human resource and marketing.

1 - Associate Professor, Faculty of Management Sciences, National University of Modern Languages, Islamabad, E-mail: fgul@numl.edu.pk 2- Assistant Professor, Bahria University, Islamabad

\begin{tabular}{llll}
\hline JISR-MSSE & Volume 15 & Number 2 & July-Dec 2017 \\
$\mathbf{1 8 1}$
\end{tabular}


Industries play a significant role in economic development of any country through increasing national income, increasing living standard, improving balance of payments, stabilizing economy, increasing employment, increasing saving and investments, increasing government revenues (Khuba, 2013). Pakistan is a developing country whose economy is not progressing at a pace it should do as the industries are not working so effectively.

According to Rawalpindi Chamber of Commerce and Industry Report, published in 2011, the second largest sector of the Pakistan's economy is the Pakistani Industrial sector contributing $25 \%$ to the GDP. Pakistan's industrial sector includes large, medium and small scale companies. At the time of independence large scales industries contribute only 1.8 percent to GDP whereas small scale industries contribution to GDP was 4.6\%. In 2010-11 contribution of both large scale and small scale sector to GDP has improved i.e. now large scale sector contributes $4.4 \%$ to GDP while small scale sector contributes $7.5 \%$ to GDP. Even after seven decades our industrial sector doesn't contribute much as it should be according to its potential and capacity. In today's era, due to intense global competition, many industries need to examine their core business processes and to formulate proactive strategies and plans to cope up with this increasingly competitive market place (Tan et al., 2000). In some of the industries productivity and cost effectiveness is declining due to which companies need to re-examine their T\&D programs (Nunnally \& Nunnally, 1998). The literature shows that there exists a strong association between competitive sources and firm's performance e.g. according to some of the past studies numerous competitiveness sources (such as production, operations, $\mathrm{R} \& \mathrm{D}$, and marketing practices) have impact on performance of the companies (Droge, Vickery, \& Markland, 1994; Li, 2000). Moreover, most of past studies are conducted in developed economies There exists a gap to conduct this research in developing countries. Little research has been conducted in Pakistan and researchers have recommended the need to conduct further research to identify the impact of core competencies on Pakistani firms' performance (Tahir et al., 2014).

This study aims to examine the impact of three business process i.e. R\&D, advertising and employees T\&D on firm's financial performance in developing country like Pakistan.

The current study provides insights into one of the most important issue faced by firms worldwide i.e. how to be competitive or how to increase and sustain their competitive advantage by studying the impact of three business processes and their impact on the financial performance of a firm. The study is helpful to both the academicians and practitioners for better understanding the impact of employees $T \& D, R \& D$ and advertisement on financial performance of firms of developing country. The study is also beneficial to top management. They can use this research and can further increase their investment in the business processes that found to have positive impact on the financial performance of their firms.

\section{LITERATURE REVIEW}

The fact that innovation and creativity play a significant role in the success of company has been widely accepted by researchers (Robinson 1986). Through R\&D a company can make superior product designs which yield to high level of functionality of a product that makes them more attractive to customers. Also R\&D results in more efficient production process which ultimately can make a company cost leader. Thus in both ways R\&D creates value to 
the company (McAlister, Srinivasan, \& Kim, 2007). The R\&D activity by the firm is meant to create innovative products and services that ultimately satisfy the needs and demands of the consumers and in doing so gain competitive edge (Burns \& Stalker, 1961). The research conducted by them found empirical evidence that investment in $R \& D$ by a firm increases stock returns and market value of a firm and it is also helpful in declining the systematic risk of the company. This indicates that the firm should invest amount in two main items that include $\mathrm{R} \& \mathrm{D}$ for the sake of innovating new items and products as well as in advertisement for marketing its products. Moreover, $R \& D$ has enabled many companies to improve or change their business processes and review the existing processes that ultimately help in reducing the wastage and time (Kong et al., 2009).

Birley \& Westhead (1990) conducted a research in which they found an empirical evidence employee training can improve the performance of the firms especially SMEs. T\&D is an important element in improving the performance of a firm, so firms should design the training very carefully (Armstrong, 2000). Cole (2002), while enlisting the benefits of training, states that training leads to high employee's morale, reduced cost of production, reduced turnover, change management, fulfillment of self-esteem and self-actualization needs, and increased employee's satisfaction. Black \& Lynch (1996) state that return on T\&D investments increase productivity by $16 \%$. Tahir et al., (2014) conduct a research study in Pakistan and find that there is a significant impact of employees T\&D on performance. The results of the study are supported by another study that shows that there is a significant impact of training on commitment level of employees and in motivating them to do work in an efficient manner (Zahra, Iram \& Naeem, 2014).

Advertisement plays a vital role in creating firm value by playing an integral role in communication strategy of the firm and by creating the brand equity through promoting the goods, services as well as ideas (Gecti \& Dastan, 2013). Mathur \& Mathur (2000) indicated that pre-launch advertisement strategies have an impact on the stock prices of the firm as it used to increase the stock price of the firm. Their work has showed that advertisements in different forms used to serve the signal of the future earning potential of the company. Pauwel et al. (2004) find that R\&D can only create the value to the firm by means of innovation but the firm can reap benefits from that innovation only after commercializing that innovation by the means of advertisement. Their research indicates that the new product introduction by the means of $R \& D$ has an impact on the company but that impact can be multiplied after commercializing that new product. Advertisement expenditures have an impact on both companies' own as well as on the competitive firm market value. Similarly, Sivanesan (2014) states that advertising is a method that is used by companies to create awareness of their products, and to make new products known to the new and potential customers. Verhoef \& Leeflang (2009) find a connection between marketing influence within the firm and a market orientation, which is beneficial to firm performance. Also, Moorman \& Rust (1999) stated that marketing sub-units contribute to financial performance, customer relationship performance, and new product performance beyond the contribution of an organization-wide market orientation. The arguments in support of a positive relationship between market orientation and business performance are well documented in the marketing literature (Langerak, 2003). Advertisement has been explored in past and literature shows that these investments are found to have a positive long term effect on numerous financial performance indicators (e.g. Dekimpe et al., 1995), and stock price (Joshi \& Hanssens, 2010; Mathur \& Mathur, 2000).

\begin{tabular}{llll}
\hline JISR-MSSE & Volume 15 & Number 2 & July-Dec 2017 \\
$\mathbf{1 8 3}$
\end{tabular}


On the basis of literature theoretical framework for the current study has been developed. Following figure depicts the relationship between R\&D, Advertisement and T\&D and company performance

Independent variables

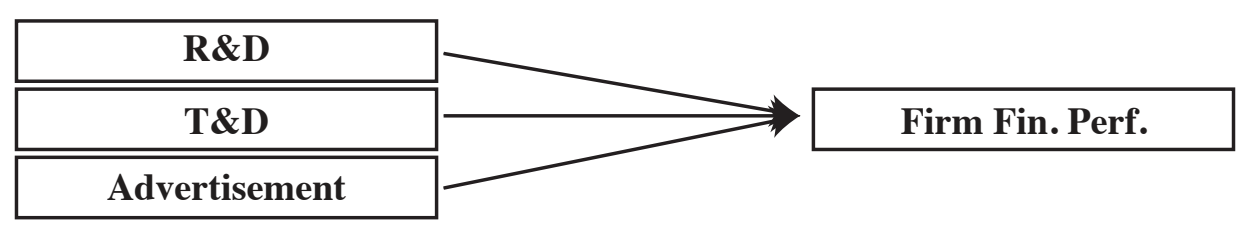

Fig. 1: Theoretical Framework of the Study

In the current study we try to substantiate the following three hypotheses:

H1. R\&D has a significant positive impact on business performance.

H2. T\&D has a significant positive impact on business performance.

H3. Advertisement has a significant positive impact on business performance.

\section{RESEARCH METHODOLOGY}

This is a primary data based research and nature of study is descriptive as it is undertaken to understand the factors that effect business performance. Questionnaires have been used to collect the data from the employees. The current study is a quantitative and empirical in nature.

Independent variables used in this study include $R \& D$, employees $T \& D$ and advertisement while the dependant variable is firm's financial performance. Data for all these variables are collected through a structured questionnaire. Financial performance of the firm is measured by using the values like its increase in the share price, profitability, sales etc. The questionnaires are distributed to the employees of the companies of two industries of manufacturing sector i.e. cement sector and pharmaceuticals. These industries are playing vital role in economic development of Pakistan and thus we have selected them from manufacturing sector.

A total of 200 questionnaires are distributed to the employees of pharmaceutical and cement companies. Out of these 164 questionnaires are received. Thus the response rate is $82 \%$. R\&D scale adapted from Srivastava (2006), advertising scale is adapted from Adekoya (2011), T\&D scale is adapted from Caicedo (2003) and financial performance scale is adapted from Chaudary et al. (2014).

\section{RESULTS AND ANALYSIS}

To assess the reliability and consistency of questionnaire, Cronbach's Alpha is used. Descriptive statistics used in the current study includes the mean, standard deviation, minimum and maximum values. Correlation analysis is conducted to assess the relationship between each independent variable with the dependent variable. Linear regression is used in the current study to assess the impact of independent variables on the dependent variable. The following regression equation is estimated: 
$Y=\beta_{0}+\beta_{1} X_{1}+\beta_{2} X_{2}+\beta_{3} X_{3}+\varepsilon_{i}$

Whereas:

$Y=$ Financial Performance, $\quad \beta_{0}=$ Constant $, \quad \beta_{1}, \beta_{2}$ and $\beta_{3}=$ Beta coefficients

$\mathrm{X}_{1}, \mathrm{X}_{2}$ and $\mathrm{X}_{3}=\mathrm{R} \& \mathrm{D}, \mathrm{T} \& \mathrm{D}$ and Advertisement, respectively and $\quad \varepsilon_{\mathrm{i}}=$ Standard error

\section{Reliability Analysis}

Table 1. Reliability Analysis: Cronbach's Alpha

\begin{tabular}{lll}
\hline Variables & No of item & Cronbach's alpha \\
\hline T\&D & 14 & .775 \\
Advertisement & 10 & .680 \\
R\&D & 13 & .882 \\
Financial performance & 6 & .822 \\
Overall Model & 43 & .814 \\
\hline
\end{tabular}

The findings show that Cronbach's alpha for T\&D is 0.775 , for advertisement is 0.680 , for $\mathrm{R} \& \mathrm{D}$ is 0.882 , for financial performance is 0.822 while for the all scale it is 0.814 . Kline (2000) and George \& Mallery (2003) have concluded that Cronbach's alpha greater than 0.6 is considered to be acceptable. Thus results indicate that in current study the scale is reliable.

\section{Descriptive Statistics}

The descriptive statistics results for the current study show a response towards "agree" for all variables as the mean values for all variables are above 3.0. The variation as indicated by Std. Dev. is small. The results are shown in table 2.

Table 2. Descriptive Statistics

\begin{tabular}{llllll}
\hline & $\mathrm{N}$ & Min & Max & Mean & Std. Deviation \\
\hline T\&D & 164 & 1.00 & 5.00 & 3.91 & .577 \\
R\&D & 164 & 1.77 & 5.00 & 3.7558 & .5079 \\
Advertisement & 164 & 1.70 & 5.00 & 3.86 & .72 \\
Fin. Perf. & 164 & 1.67 & 5.00 & 3.948 & .5650 \\
\hline
\end{tabular}

Table 3. Correlations between Measures

\begin{tabular}{lllll}
\hline & T\&D & Advertisement & R\&D & Fin. Perf. \\
\hline T\&D & 1 & & & \\
Advertisement & $.277^{* *}$ & 1 & & \\
R\&D & $.556^{* *}$ & $.280^{* *}$ & 1 & \\
Fin. Perf. & $.409^{* *}$ & $.268^{* *}$ & $.543^{* *}$ & 1 \\
\hline
\end{tabular}

Note. $* * \mathrm{P}<0.01$ level (2-tailed). 
Researchers usually consider significance value of $95 \%$ which shows that there can only be a $5 \%$ chance of error. The results depicted that there exist a significant positive relation between independent and dependent variables i.e. $T \& D, R \& D$, and advertisement have significant positive correlation with the financial performance.

\section{Regression Results and Analysis}

In order to substantiate the hypotheses, multiple linear regression is used in this study. The regression results for the current study are shown in table 4 . The overall model fit for regression equation is shown by $\mathrm{F}$ statistics. For the current model F-value is 48.339 which is statistically significant at a 0.01 level of significance.

Table 4. Regression Results

\begin{tabular}{lllll}
\hline Variables & Beta & Std. error & t-stats & Sig. \\
Constant & 1.277 & .230 & 5.55 & .000 \\
R\&D & .486 & .064 & $7.61^{* * *}$ & .000 \\
Advertisement & .085 & .039 & $2.19^{* *}$ & .030 \\
T\&D & .133 & .056 & $2.37 * *$ & .019 \\
\hline
\end{tabular}

$\mathrm{R}=0.567, \mathrm{R}^{2}=0.322$, Adj. $\mathrm{R}^{2}=0.315, \mathrm{~F}-$ value $=48.339^{* * *}, \mathrm{p}<0.01$, *** significant at the 0.01 level, **significant at the 0.05 level

The regression results show that $32.2 \%$ of variance in the dependent variable, i.e. financial performance, is due to independent variables, i.e. $R \& D$, advertisement and employees T\&D). $R \& D$ has the highest beta of 0.486 followed by $T \& D$, having beta of 0.133 , and advertisement, having beta of 0.085 . Also if we look at the t-statistics the results show that all three independent variables have a statistically significant impact on firm's financial performance. Thus all three alternate hypotheses, $\mathrm{H}_{1}, \mathrm{H}_{2}$ and $\mathrm{H}_{3}$, are accepted.

Industry-wise Results

Cement Industry Regression Results

Table 5. Regression Results for Cement Industry

\begin{tabular}{lllll}
\hline Variables & Beta & Std. error & t-stats & Sig. \\
Constant & 5.292 & .337 & 8.046 & .000 \\
R\&D & -.718 & .231 & $-3.102^{* * *}$ & .003 \\
Advertisement & .107 & .049 & $2.166^{* *}$ & .035 \\
T\&D & .239 & .247 & .965 & .339 \\
\hline
\end{tabular}

$\mathrm{R}=0.491, \mathrm{R}^{2}=0.241$, Adj. $\mathrm{R}^{2}=0.198, \mathrm{~F}$-value $=5.703, \mathrm{p}<0.01, * * *$ significant at the 0.01 level $* *$ significant at the 0.05 level

The results show that in cement industry $24.1 \%$ of variance in the financial performance is due to investment in $R \& D$, advertisement and employees $T \& D$. In cement industry $R \& D$ variable has the negative beta of -0.718 whereas advertisement has positive beta of 0.107 . Both these betas are statistically significant. Whereas employees $T \& D$ is insignificant as $p>0.1$ and 
t-value is less than 1.96. Pakistani cement companies use advertisement to increase their financial performance while their R\&D activity significantly decrease their performance. On the other hand, employees' T\&D is not having an impact on their financial performance. As the industry is working in a stable environment and there is no abrupt changes in the technology or processes due to which companies' investment in R\&D is very low. The product life cycle of the cement industry is very long; it is working in a stable environment due to which company investment in employees' T\&D as well as R\&D doesn't impact heavily on its financial performance. So companies consider these to be expenses rather than investments. Moreover, customers don't know much about the technical aspects of cement sold by different companies thus customers used to rely on the information that they gather from different sources. Due to this reason cement companies use to invest in advertisement and results also depict that advertisement has significant positive impact on financial performance. Cement companies don't invest much on $\mathrm{R} \& \mathrm{D}$ as it is a homogenous product that can't be differentiated from others. As production process is also uniform so frequent training programs are also not very much important in improving the financial performance of the firm.

\section{Pharmaceutical Regression Results}

Table 6. Regression Results for Pharmaceutical Industry

\begin{tabular}{lllll}
\hline Variables & Beta & Std. error & t-stats & significance \\
constant & 2.838 & .920 & 3.086 & .003 \\
R\&D & .580 & .175 & $3.316^{* * *}$ & .001 \\
Advertisement & -.358 & .121 & $-2.96 * * *$ & .004 \\
T\&D & .091 & .184 & .493 & .623 \\
\hline
\end{tabular}

$\mathrm{R}=0.486, \mathrm{R}^{2}=0.236, \mathrm{Adj} . \mathrm{R}^{2}=0.206, \mathrm{~F}-\mathrm{value}=8.02, \mathrm{p}<0.01, * * *$ significant at the 0.01 level $* *$ significant at the 0.05 level

The results show that in pharmaceutical industry $23.6 \%$ of variance in the financial performance is due to investment in $\mathrm{R} \& \mathrm{D}$, advertisement and employees $\mathrm{T} \& \mathrm{D}$. The findings show that R\&D has the highest beta of 0.580 followed by $T \& D$, having a beta of 0.091 but statistically insignificant as its p-value $>0.1$. Advertisement has a negative beta of -0.358 . These results depict that pharmaceutical firms are actively involved in R\&D activities to increase their financial performance. The higher the ratio of investment in R\&D better is the financial performance. Pharmaceutical companies need to conduct extensive R\&D to develop new formulas or medicines that are meant to cure the diseases in a better way than the existing medicine. In pharmaceutical industry the advertisement doesn't directly impact the sales or performance of the company rather it is the trust level that increases the sales of the product. In pharmaceutical industry patients rely on doctors prescriptions. So companies use to advertise their products directly to doctors and try to convince them regarding the benefits offered by the medicines. The regression result also demonstrates the negative beta coefficient for the advertisement that depicts that advertisement doesn't increase the sales of the company rather it has negative impact on financial performance. 


\section{How the Results of the Current Study Support Literature}

The results of the current study support the results of the previous studies. As the regression results indicate that for any firm in Pakistan advertising, R\&D and T\&D cause around 32\% of variance in its financial performance. Literature also support the importance and impact of these processes on firm's performance e.g. Nickels et al. (1999) in their research find that advertising helps a firm to get competitive position and to improve its financial performance. Similarly a study by Glover (1999) states that increase in the level of employee training by a firm is related with the increase in level of its productivity. Snow \& Hrebiniak (1980) in their research point out the significance of firm's business processes by stating that these functional areas can become core competencies of any firm which ultimately improve their performance. Hitt \& Ireland (1985) in their research explore that marketing activities are positively related to firm's performance. Similarly Droge et al. (1994) in their research have taken a sample of 65 firms from furniture industry and their findings indicate that product development and marketing activities are positively related to firm's performance. Black \& Lynch (1996) citing Bishop (1994) demonstrate that T\&D increases performance and productivity of a firm by $16 \%$. Moreover our research indicates that advertisement has insignificant impact on the performance of pharmaceutical firms. Literature also depicts that direct to consumer advertising is being criticized by many physicians (Dickson, 2001; Gellad \& Lyles, 2007; Silver, Stevens \& Loudon, 2009). In most countries, including Pakistan, the practice of direct to customer marking of pharmaceutical products, except generic medicine, is prohibited. Therefore, the results are in accordance with the legal restrictions in Pakistan.

\section{CONCLUSION}

In the current era, due to intense global competition and technological advancement, companies need to put more emphasis on their core functional competencies. Now-a-days companies all over the world have understood the importance of human resource practices, especially $T \& D$, marketing practices, especially advertisement and $R \& D$ to be competitive. The current study aims to examine the impact of these three business processes i.e. $R \& D$, advertising and employees T\&D on financial performance. The results indicate that in Pakistani industries (cement and pharmaceutical) companies are putting emphasis on giving training to their employees, introducing new technological methods, processes and products through investing in R\&D activities and creating awareness among customers through investment in advertisement practices. Companies perceive these three business processes as investment, and not only as expenditure, which ultimately can increase their financial performance. The results also indicate that in the two industries selected in this study around $32 \%$ of variance in financial performance of a firm is due to investment in these three business processes. However, according to industry nature of operations and competition intensity the impact of these three business processes (i.e. $R \& D, T \& D$ and advertisement) on financial performance vary, as shown in the individual regression results for the two industries. For example, pharmaceutical companies of Pakistan actively involve itself in R\&D activities to increase their financial performance whereas in cement industry the beta coefficient for R\&D is statistically insignificant. On the other hand, cement companies are actively involved in advertising their products to be competitive. The three hypotheses stated in the current study have been substantiated and the results of the study are also supported by historical literature. Industry-wise differences are also demonstrated and discussed in detail. Literature also states that firms which invest in $R \& D$ and human resource activities yield better financial performance and provide them sustainable competitive advantage (Ndofor, Sirmon, \& He,

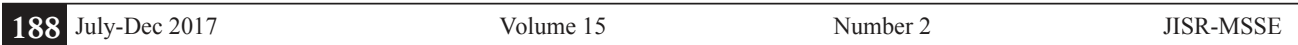


2011). The research has concluded that these business processes are vital in improving the competitive advantage of any firm and ultimately the financial performance of that firm.

\section{CONTRIBUTIONS}

The current study makes the following contributions in the field of research:

First, the results of current study provide insights into one of the most important issue faced by companies worldwide i.e. how to be competitive or how to increase and sustain their financial performance. In past, most of the research investigated the impact of any one business process on firm's financial performance (Capon, Farley, \& Hoenig, 1990; Drucker, 1976; Ettlie, 1997; Hayes \& Wheelwright, 1984; Tunaly, 1992) while this study explores the impact of three business processes simultaneously on firm's financial performance. Also in past most of the researches are being conducted in the developed countries where the technological condition, infrastructure and facilities are different than developing countries. The current study explores the significance of these business processes in a developing country like Pakistan.

Second contribution of the current study is its comprehensive discussion and analysis. The results of the current study supports and have confirmed the results of previous studies, especially for business processes like R\&D and HR competencies. The findings of this study are useful for top level management. The results signify that investment in R\&D, advertisement and employee $T \& D$ is a financially viable investment and it brings benefits in the form of improved financial performance.

\section{RECOMMENDATIONS FOR FUTURE RESEARCH}

The current study is focused on the impact of three business processes on financial performance of a firm. Future research may consider the impact of other business processes like manufacturing, accounting, logistics etc. on financial performance of a firm which can help in better understanding of the impact of all business processes on financial performance of a firm. Moreover the current study focuses on manufacturing sector; in future research can be conducted to find the impact of business processes on the financial performance of service sector.

This study is based on primary data which collects data using a structured questionnaire. Future research can be conducted by using secondary collected directly from the financial statements/ annual reports. Future researchers can take the exact amount of money been invested in these business processes and then linking it to financial performance indicators e.g. ROA, ROE, ROI, profit margins, etc. of firm. 


\section{REFERENCES}

Abel, G. A., Penson, R. T., Joffe, S., Schapira, L., Chabner, B. A., \& Lynch, T. J. (2006). Direct-to-consumer advertising in oncology. The Oncologist, 11(2), 217-226.

Adekoya, O. A. (2011). The Impact of Advertising on Sales Volume of a Product: A case of Starcomms Plc, Nigeria (Unpublished Bachelor Thesis). HAMK University of Applied Sciences, Nigeria.

Armstrong, M. (2000). The name has changed but has the game remained the same? Employee Relations, 22(6), 576-593.

Black, S. E., \& Lynch, L. M. (1996). Human-capital investments and productivity. The American Economic Review, 86(2), 263-267.

Birley, S., \& Westhead, P. (1990). Growth and performance contrasts between 'types' of small firms. Strategic management journal, 11(7), 535-557.

Burns, T. E., \& Stalker, G. M. (1961). The management of innovation. University of Illinois at Urbana-Champaign's Academy for Entrepreneurial Leadership Historical Research Reference in Entrepreneurship.

Caicedo, L. M. (2003). Training and Motivation: Key to a Quality and Productivity-driven Company Culture (Doctoral dissertation, University of Florida).

Capon, N., Farley, J. U., \& Hoenig, S. (1990). Determinants of financial performance: a meta-analysis. Management Science, 36(10), 1143-1159.

Chaudary, S., Zafar, S., \& Salman, M. (2015). Does total quality management still shine? Re-examining the total quality management effect on financial performance. Total Quality Management \& Business Excellence, 26(7-8), 811-824.

Cole, G. A. (2002). Personnel and human resource management. Cengage Learning EMEA.

Dekimpe, M. G., \& Hanssens, D. M. (1995). The persistence of marketing effects on sales. Marketing science, 14(1), 1-21.

Droge, C., Vickery, S., \& Markland, R. E. (1994). Sources and outcomes of competitive dvantage: an exploratory study in the furniture industry. Decision Sciences, 25(5-6), 669-689.

Drucker, P. F. (1976). Managing the public service institution. College \& Research Libraries, 37(5), 1-14

Ettlie, J. E. (1997). Integrated design and new product success. Journal of Operations Management, 15(1), 33-55.

Frosch, D. L., Krueger, P. M., Hornik, R. C., Cronholm, P. F., \&Barg, F. K. (2007). Creating demand for prescription drugs: a content analysis of television direct-to-consumer advertising. The Annals of Family Medicine, 5(1), 6-13.

Gellad, Z. F., \& Lyles, K. W. (2007). Direct-to-consumer advertising of pharmaceuticals. The American journal of medicine, 120(6), 475-480.

Gecti, F., \& Dastan, I. (2013). The Impact of Social Media-Focused Information \& Communication Technologies on Business Performance via Mediating Mechanisms: An Exploratory Study on Communication and Advertising Agencies in Turkey. IJBM, 8(7), 106-115.

George, D., \& Mallery, P. (2003). SPSS for Windows step by step: A simple guide and reference. (4th ed.). Boston: Allyn\& Bacon.

Glover, R. W., Long, D. W., Haas, C. T., \& Alemany, C. (1999). Return-on-investment (ROI) Analysis of education and training in the construction industry (Vol. 6). Center for Construction Industry Studies. 
Hayes, R. H., \& Wheelwright, S. C. (1984). Restoring our Competitive Edge: Competing Through Manufacturing. John Wiley \& Sons, New York, NY.

Hitt, M. A., \& Ireland, R. D. (1985). Corporate distinctive competence, strategy, industry and performance. Strategic Management Journal, 6(3), 273-293.

Joshi, A., \& Hanssens, D. M. (2010). The direct and indirect effects of advertising spending on firm value. Journal of Marketing, 74(1), 20-33.

Kong, M. G., Kroesen, G., Morfill, G., Nosenko, T., Shimizu, T., Van Dijk, J., \& Zimmermann, J. L. (2009). Plasma medicine: an introductory review. New Journal of Physics, 11(11), 115012 .

Khuba, S. C. Role and importance of industries in Indian economy. Indian Streams Research Journal, 3(1), 1-8.

Kline, P. (2000). The handbook of psychological testing (2nd edn.). Routledge, London.

Landefeld, C. S., \& Steinman, M. A. (2009). The Neurontin legacy-Marketing through misinformation and manipulation. New England Journal of Medicine, 360(2), 103-106.

Langerak, F. (2003). The effect of market orientation on positional advantage and organizational performance. Journal of Strategic Marketing, 11(2), 93-115.

Li, L. X. (2000). An analysis of sources of competitiveness and performance of Chinese manufacturers. International Journal of Operations \& Production Management, 20(3), 299-315.

Mathur, L. K., \& Mathur, I. (2000). An analysis of the wealth effects of green marketing strategies. Journal of Business Research, 50(2), 193-200.

McAlister, L., Srinivasan, R., \& Kim, M. (2007). Advertising, research and development, and systematic risk of the firm. Journal of Marketing, 71(1), 35-48.

Moorman, C., \& Rust, R. T. (1999). The role of marketing. The Journal of Marketing, 63(special Issue), 180-197.

Ndofor, H. A., Sirmon, D. G., \& He, X. (2011). Firm resources, competitive actions and performance: investigating a mediated model with evidence from the in-vitro diagnostics industry. Strategic Management Journal, 32(6), 640-657.

Nunnally, S. W., \& Nunnally, S. W. (1998). Construction methods and management (Vol. 3). Prentice Hall.

Porter, M. E. (2008). Competitive advantage: Creating and sustaining superior performance. Simonand Schuster.

Robinson, H. (1986). Marketing Expenditures as Capital Investment. European Journal of Marketing, 20(1), 83-94.

Silver, L., Stevens, R., \& Loudon, D. (2009). Direct-to-Consumer Advertising of Pharmaceuticals: Concepts, Issues, and Research. Health Marketing Quarterly, 26(4), 251-258.

Sivanesan, R. (2014). Impact of Brand image and advertisement on consumer buying behavior-Comparative study on rural and urban consumers. International Journal of Research in Management and Business Studies, 1(2), 73-80.

Tan, K.C., Kannan, V.R., Handfield, R.B., \& Ghosh, S. (2000). Quality, manufacturing strategy, and global competition: an empirical analysis. Benchmarking: An International Journal, 7(3), 174-182.

Snow, C.C. \& Hrebiniak, L.G. (1980). Strategy, distinctive competence, and organizational performance. Administrative Science Quarterly, 25(2), 317-336.

\begin{tabular}{llll}
\hline JISR-MSSE & Volume 15 & Number 2 & July-Dec 2017 \\
\hline
\end{tabular}


Srivastava, P. (2006). Effect of New Product Development Project Portfolio Mix on New Product Development Program Performance (Doctoral dissertation, Oklahoma State University).

Tahir, N., Yousafzai, I. K., Jan, S., \& Hashim, M. (2014). The Impact of Training and Development on Employees Performance and Productivity A case study of United Bank Limited Peshawar City, KPK, Pakistan. International Journal of Academic Research in Business and Social Sciences, 4(4), 86-98.

Verhoef, P. C., \& Leeflang, P. S. (2009). Understanding the marketing department's influence within the firm. Journal of Marketing, 73(2), 14-37.

Zahra, S., Iram, A., \& Naeem, H. (2014). Employee Training and Its Effect on Employees Job Motivation and Commitment: Developing and Proposing a Conceptual Model. IOSR Journal of Business and Management, 16(9), 60-68. 